\title{
Direct greenhouse gas emissions of the game industry in South Africa
}

\author{
C.J.L. du Toit ${ }^{1,3 \#}$, H.H Meissner ${ }^{2}$ \& W.A. van Niekerk ${ }^{3}$ \\ ${ }^{1}$ Department of Animal Science, Tshwane University of Technology, Private Bag X680, Pretoria,0001, South Africa \\ ${ }^{2} 189$ van Riebeeck Avenue, Lyttelton Manor, Centurion, 0157, South Africa \\ ${ }^{3}$ Department of Animal and Wildlife Sciences, University of Pretoria, 0002, South Africa
}

Copyright resides with the authors in terms of the Creative Commons Attribution 2.5 South African Licence.
See: http://creativecommons.org/licenses/by/2.5/za
Condition of use: The user may copy, distribute, transmit and adapt the work, but must recognise the authors and the South African Journal of Animal
Science.

\begin{abstract}
Previous greenhouse gas (GHG) inventories did not include game as an emissions source. Recently game farming has become a recognized commercial enterprise in the agricultural sector in South Africa, contributing approximately R10 billion to the sectorial gross domestic product. The objective of this study was to estimate methane $\left(\mathrm{CH}_{4}\right)$ and nitrous oxide $\left(\mathrm{N}_{2} \mathrm{O}\right)$ emissions from privately owned game animals based on international recognized methodologies. The emissions were calculated on the basis of a large stock unit (LSU) selecting different quality diets. Daily enteric methane emissions were estimated as $0.28,0.22$, and $0.18 \mathrm{~kg} \mathrm{CH}_{4} / \mathrm{LSU} /$ day consuming diets of $55 \%, 65 \%$ and $75 \%$ digestibility, respectively. The game industry contributed an estimated 131.9 Giga grams $(\mathrm{Gg})$ of methane annually to agricultural emissions with the provinces of Limpopo, Eastern Cape and Northern Cape being the three largest contributors with 43.4, 37.3 and $21 \mathrm{Gg}$ methane, respectively. The total privately owned game population was estimated at 2991370 animals, utilizing 20.5 million hectares.
\end{abstract}

Keywords: Methane, nitrous oxide, wildlife, emission factors

"Corresponding author: dutoitcjl@tut.ac.za

\section{Introduction}

Game or wild ungulates have always inhabited southern Africa, although the population size has fluctuated greatly over the past 100 years. The establishment and growth of the private game industry is largely responsible for an increase in the number of game in recent years (Eloff, 2002; Bothma \& Van Rooyen, 2005). Similarly, the industry has shown a steady growth in the number of game farms from 2280 in 1980 to 9000 in 1992 (Nell, 2003) and approximately 10000 currently (G. Dry, 2013, Pers. Comm., Wildlife Ranching South Africa, P.O. Box 23073, Gezina, 0031, South Africa). The private game ranching industry occupies 16.8\% (20 500000 ha) of South Africa's total land area. This figure equates to $24 \%$ of South Africa's 84 million hectares of grazing land (Dry, 2011). This is more than double the area of officially declared conservation areas and approximately fivefold the area of the national parks (Carruthers, 2004).

Game farming or ranching has become an organized and recognized enterprise in the agricultural industry (Eloff, 1996; Van Der Waal \& Dekker, 2000). According to a recent article by Van Rooyen (2013) the wildlife industry ranked fifth largest in the agricultural sector, contributing R10 billion to the country's gross domestic product (GDP). Game farming is defined as an agricultural system in which wild animals are maintained in order to harvest by-products such as meat and skins in a domesticated or semi-domesticated manner by being enclosed in relatively small areas and provided with regular supplementary feeding and water (Carruthers, 2004; Du Toit, 2007). Part of the success of the industry is the ability of game to produce higher returns, compared to conventional livestock farming, under particular circumstances that may enhance the utilization of land with low agricultural potential (ABSA, 2003).

Herbivorous game, with the exception of elephant, rhinoceros, hippopotamus, zebra, warthogs and bushpigs, are ruminants. Ruminants contribute to greenhouse gas (GHG) emissions through methane 
emissions directly from digestive processes and methane $\left(\mathrm{CH}_{4}\right)$ and nitrous oxide $\left(\mathrm{N}_{2} \mathrm{O}\right)$ emissions originating from manure. The quantity of $\mathrm{CH}_{4}$ produced by ruminants is influenced by the level of intake, composition of the diet, and level of production of the animal. Game species select for diet quality in accordance with their feeding habits, and were classified by Hofmann (1973) as bulk and roughage eaters (grazers), selectors of concentrated herbage (browsers) and intermediate feeders (grazing and browsing). These three groups typically select diets with an approximate digestibility of $55 \%, 75 \%$ and $65 \%$, respectively (Meissner et al., 1983). These differences in diet quality influence energy intake as well as the amount of gross energy intake, which is lost as methane and thus methane emissions.

Game is considered a source of anthropogenic emissions. Previous GHG inventories for the livestock sector in South Africa did not include privately owned game as an emission source. The game industry has developed into a commercial farming sector, and emissions from all such sectors in the livestock industry need to be included in order to provide a complete and representative emissions inventory of the livestock sector. The aim of this study was to calculate methane emissions originating from privately owned game.

\section{Methodology}

Various sources have reported on the privately owned game population, which have varied from as low as 1.7 million (Van der Merwe \& Saayman, 2003), to 2.5 million (G. Dry, 2013, Pers. Comm., Wildlife Ranching South Africa, P.O. Box 23073, Gezina, 0031, South Africa), to 9 million (NAMC, 2006), to 16 million (Van Rooyen, 2013), to as high as 18.6 million (ABSA, 2008). The majority of sources agreed on the surface area under private game nationally of 20.5 million hectares (NAMC, 2006; ABSA, 2008; Cousins et al., 2008, Dry, 2011). Owing to the large variations in literature quotes of the number of privately owned game in South Africa, game emissions were calculated according to the grazing capacity of an area on a provincial basis in terms of large stock units (LSU) and were not based on individual population figures.

The calculations followed the principles of the IPCC (2006) guidelines. Grazing capacity is defined as the area of land required to maintain a single LSU over an extended number of years without deterioration of the vegetation or soil. It was assumed that wildlife farmers stock their farms according to the ecological carrying capacity of the farm. Table 1 indicates the number of exempted game farms in South Africa, based on data from 2000, according to Eloff (2002) and Van der Merwe \& Saayman (2003).

Table 1 Proportion of exempted game farms in South Africa (Eloff, 2002; Van der Merwe \& Saayman, 2003)

\begin{tabular}{lcc}
\hline Province (year 2000) & \% of game farms & $\begin{array}{c}\text { \% of game farms according to } \\
\text { hectares }\end{array}$ \\
\hline Free State & 3.56 & 1.43 \\
Limpopo & 49.0 & 32.1 \\
North West & 6.72 & 3.51 \\
Mpumalanga & 4.05 & 2.66 \\
Gauteng & 1.42 & 0.79 \\
KwaZulu-Natal & 1.78 & 1.63 \\
Eastern Cape & 12.3 & 8.51 \\
Northern Cape & 19.5 & 46.8 \\
Western Cape & 1.62 & 2.56 \\
Total & 100 & 100 \\
\hline
\end{tabular}

Similar ratios on the percentage of game farms per province have been reported by ABSA (2008) and Dry (2011), although the total surface area of the game farms has increased from 10.4 million hectares in 2000 (Eloff, 2002) to 20.5 million hectares currently (Dry, 2011). The estimation of the surface area of private game farms per province was based on the ratio reported in Table 1 and the national total of 20.5 
million hectares. The emissions calculations in this study were based on surface area under game farms incorporating carrying capacity of regions, owing to the uncertainty in game population numbers.

Provinces in South Africa were divided into five ecological regions, namely Grassland, Lowveld, Bushveld, Kalahari and Karoo, according to Bredenkamp et al. (1996). Grassland is defined as the higher inner plateau with an annual rainfall of between $500 \mathrm{~mm}$ and $800 \mathrm{~mm}$, dominated by various grass types with limited trees and shrubs. The Lowveld, Bushveld and Kalahari regions are grouped as savannah areas. The Lowveld region covers low-lying areas east of the Northern Drakensberg escarpment with an annual rainfall of between $400 \mathrm{~mm}$ and $600 \mathrm{~mm}$. The Bushveld region refers to the northern parts of South Africa, west of the Drakensberg escarpment, including the Limpopo valley, with an annual rainfall of between $300 \mathrm{~mm}$ and $600 \mathrm{~mm}$. The Kalahari region is classified as arid savannah, with an annual rainfall of between $200 \mathrm{~mm}$ and $400 \mathrm{~mm}$ per annum. The western part of the Karoo region is classified as semi-desert with an annual rainfall of less than $200 \mathrm{~mm}$ (Bredenkamp et al., 1996; ABSA, 2003). The ecological carrying capacity (ha/LSU) of these regions was reported by ABSA (2003) as 4, 12, 15, 30, and 55 for Grassland, Lowveld, Bushveld, Kalahari and Karoo regions, respectively. The average farm size was estimated according to data reported by Van der Merwe \& Saayman (2003). The area per ecological region per province is reported in Table 2.

Table 2 Average game farm size and surface area of ecological regions per province in South Africa

\begin{tabular}{|c|c|c|c|c|c|c|c|}
\hline \multirow[b]{2}{*}{ Province } & \multirow{2}{*}{$\begin{array}{c}\text { Total } \\
\text { area (ha) } \\
\left({ }^{\prime} 000\right)\end{array}$} & \multirow{2}{*}{$\begin{array}{c}\text { Ave } \\
\text { farm size } \\
\text { (ha) }\end{array}$} & \multicolumn{5}{|c|}{ Surface area/ ecological region/ province } \\
\hline & & & $\begin{array}{c}\begin{array}{c}\text { Grassland } \\
\text { (ha) }\end{array} \\
\end{array}$ & $\begin{array}{c}\text { Lowveld } \\
\text { (ha) }\end{array}$ & $\begin{array}{c}\text { Bushveld } \\
\text { (ha) }\end{array}$ & $\begin{array}{c}\begin{array}{c}\text { Kalahari } \\
\text { (ha) }\end{array} \\
\end{array}$ & $\begin{array}{c}\text { Karoo } \\
\text { (ha) }\end{array}$ \\
\hline Free State & 287 & 821 & 206066 & & & 18942 & 61992 \\
\hline Limpopo & 6581 & 1340 & 210576 & 921270 & 5461815 & 6581 & \\
\hline North West & 718 & 1073 & 208075 & & 157850 & 351575 & \\
\hline Mpumalanga & 554 & 146 & 354240 & 132840 & 66420 & & \\
\hline Gauteng & 164 & 1140 & 127104 & & 36900 & & \\
\hline $\mathrm{KZN}$ & 328 & 1876 & 118080 & 101680 & 108240 & & \\
\hline Eastern Cape & 1743 & 1413 & 702809 & & 476284 & & 563409 \\
\hline Northern Cape & 9594 & 4921 & 32620 & & & 2830230 & 6732110 \\
\hline Western Cape & 533 & 3234 & 5330 & & 26650 & & 501020 \\
\hline
\end{tabular}

KZN: KwaZulu-Natal.

It was assumed that approximately $30 \%$ of the farms per province are larger than the average farm size according to research by Van der Waal \& Dekker (2000). The habitat and size of the farm influence the minimum herd size and relative species distribution of a game farm (Appendices 1A \& 1B). The total LSUs according to the ecological carrying capacity on a provincial basis are given in Table 3. A LSU is defined as a steer of $450 \mathrm{~kg}$, which gains $500 \mathrm{~g} /$ day on a pasture with a mean digestibility (DE) of 55\% (Meissner et al., 1983). The proportion of grazers, browsers and mixed feeders as a percentage of total large stock units per ecological region is reported in Table 4. The relative distribution of animal species on private game farms is different from that of national parks in South Africa (ABSA, 2003) and varies according to the size of the farm. The relative distributions of animal species and herd size per ecological region for small and large farms are reported in Appendices 1A and 1B.

Enteric methane emissions originating from game were calculated based on dry matter intake (I), (kg $\mathrm{DM} / \mathrm{head} /$ day). The daily intake of animal types was calculated based on metabolizable energy requirements (MJ/day) of large stock units according to Meissner et al. (1983). The daily metabolizable energy (ME) requirements (MJ/day) of animals selecting diets with various levels of digestible energy concentrations were based on the net energy requirements of an LSU and the efficiency coefficients of ME utilization at a certain level of production, according to Meissner et al. (1983). Daily intake per animal type was calculated by dividing the $\mathrm{ME}$ requirement (MJ/day) by the $\mathrm{ME}$ concentration $(\mathrm{MJ} / \mathrm{kg})$ of the selected diet. 
Table 3 Distribution of large stock units per province according to ecological carrying capacity

\begin{tabular}{lrcr}
\hline \multirow{2}{*}{ Province } & \multicolumn{3}{c}{ Large stock units } \\
\cline { 2 - 4 } & Large farm & Small farm & Total \\
\hline Free State & 15982 & 36946 & 52928 \\
Gauteng & 10271 & 23965 & 34236 \\
Limpopo & 148127 & 345631 & 493758 \\
Mpumalanga & 31217 & 72841 & 104058 \\
KwaZulu-Natal & 13563 & 32396 & 45959 \\
Western Cape & 3666 & 8554 & 12220 \\
Northern Cape & 67470 & 157429 & 224899 \\
North West & 22279 & 51982 & 74261 \\
Eastern Cape & 64803 & 334382 & 399185 \\
\hline
\end{tabular}

Table 4 Animal types per ecological region as a percentage of large stock units (ABSA, 2003)

\begin{tabular}{lccccc}
\hline \multirow{2}{*}{ Animal type } & \multicolumn{5}{c}{ Ecological region } \\
\cline { 2 - 6 } & Grassland & Lowveld & Bushveld & Kalahari & Karoo \\
\hline Low selective grazers & 20 & 25 & 20 & 10 & 2 \\
High selective grazers & 50 & 30 & 30 & 65 & 60 \\
Mixed feeders & 28 & 25 & 30 & 20 & 35 \\
Browsers & 2 & 20 & 20 & 5 & 3 \\
\hline
\end{tabular}

Daily enteric methane (M), (kg/head/day) production was calculated according to Kurihara et al. (1999) based on emissions from cattle fed tropical grass species as:

$$
M=(34.9 \times I-30.8) / 1000
$$
(2009) as:

Methane emissions from manure (M), (kg/head/day) of all game were calculated according to ANIR

$$
\begin{aligned}
& \text { M = I x (1 - DMD) x MEF } \\
& \begin{array}{ll}
\text { Where: } & \text { I = dry matter intake (kg DM/head/day) } \\
& \text { MEF = emissions factor ( } \mathrm{kg} \mathrm{CH} / \mathrm{kg} \text { DM manure). The factor of } 1.4 \times 10^{-5} \\
& \text { based on the work of Gonzalez-Avalos \& Ruiz-Suarez (2001) was used. } \\
& \text { DMD = diet digestibility ( } 55 \% \text { for grazers, } 65 \% \text { for browsers and } 75 \% \text { for } \\
& \text { concentrate selectors). }
\end{array}
\end{aligned}
$$

Game production systems are mainly extensive and manure is deposited directly on veld or rangeland. According to the IPCC (2006), $\mathrm{N}_{2} \mathrm{O}$ emissions from manure deposited on rangeland or veld are reported under the managed soils section in the national inventory report format and not under livestock emissions. Nitrous oxide emissions originating from faeces and urine deposited on rangeland was calculated according to the ANIR (2009). 


\section{Results and Discussion}

Game farming has become a recognized agricultural enterprise (Bothma, 1995; Eloff, 1996; Van der Waal \& Dekker, 2000) but previous agricultural GHG inventories did not include game farming as an emission source (Blignaut et al., 2005; Otter, 2010). The daily intake, estimated $\mathrm{CH}_{4}$ emissions originating from enteric fermentation and manure, and estimated $\mathrm{N}_{2} \mathrm{O}$ emissions from faecal matter deposited on soils from large stock units selecting various diets are presented in Table 5.

Table 5 Estimated daily intake, methane and nitrous oxide emissions of large stock units selecting different diet qualities

\begin{tabular}{lccccc}
\hline Animal class & $\begin{array}{c}\text { Diet } \\
\text { digestibility } \\
\mathbf{( \% )}\end{array}$ & $\begin{array}{c}\text { Intake (kg } \\
\text { DM/day) }\end{array}$ & $\begin{array}{c}\text { Enteric } \mathbf{C H}_{4} \\
\text { (kg/head/day) }\end{array}$ & $\begin{array}{c}\text { Manure } \mathbf{C H}_{4} \\
\text { (kg/head/day) }\end{array}$ & $\begin{array}{c}\text { Soil } \mathbf{N}_{\mathbf{2}} \mathbf{O} \\
\text { (kg/head/day) }\end{array}$ \\
\hline Grazer & 55 & 8.81 & 0.277 & $5.6 \times 10^{-5}$ & $5.4 \times 10^{-4}$ \\
$\begin{array}{l}\text { Intermediate } \\
\text { feeders }\end{array}$ & 65 & 7.08 & 0.216 & $3.5 \times 10^{-5}$ & $7.4 \times 10^{-4}$ \\
Browsers & 75 & 5.89 & 0.175 & $2.1 \times 10^{-5}$ & $1.07 \times 10^{-3}$ \\
\hline
\end{tabular}

Every farm differs and has its own unique carrying capacity and game composition potential. The number of animals kept on a land unit is determined by the size of the habitat area, the carrying capacity of the unit, the social and spatial needs of the animals, as well as the interaction and composition of the animal species (Furstenburg, 2011). Domestic livestock have lost their natural social structure and territorial behaviour over the years, and carrying capacity is based on fodder production, consumption and veld type (Furstenburg, 2011). The carrying capacity on game farms incorporates animal social needs and habitat requirements. The use of grazing capacity as a base for the calculations is a source of uncertainty, as there is a difference between the grazing capacity of the veld and the stocking rate. Grazing capacity refers to the true number of animals the vegetation can sustain, and the stocking rate to the number of animals the farm manager perceives it can sustain (Smit, 2012). Smit (2012) stated that the use of LSU values for herbivorous game species does not allow for ecological separation, and overlooks the potential for using the specialized and complementary resource-use habits of wildlife to maximize veld utilization. The approach, however, is based on sound scientific principles and the error associated with an approach based on individual animal numbers will be larger owing to the large variation in reported game population numbers in South Africa.

The methane emissions of wildlife on private game farms per province are presented in Table 6 . The game industry contributes an estimated $132 \mathrm{Gg}$ in methane emissions per annum. These figures were calculated based on the average carrying capacity of game farms in each province. Limpopo was the largest contributor in terms of methane emissions from farmed wildlife followed by Eastern Cape and Northern Cape, with $43.4 \mathrm{Gg}$ (32.9\%), $37.3 \mathrm{Gg}$ (28.3\%) and $21 \mathrm{Gg}(15.9 \%)$ respectively of the total emissions. The emission calculations were based on LSUs as defined by Meissner et al. (1983). This may lead to a possible over-estimation of game emissions, as not all game animals are ruminants. Northern Cape has the largest surface area under private game farming (46.8\%), followed by Limpopo (32.1\%) and Eastern Cape (8.5\%). The difference between provincial ranking according to surface area and methane emissions is because of the average carrying capacity of the provinces. Northern Cape has the largest surface area under private game farming, but it ranks only third in terms of methane emissions originating from private game. This is owing to the relatively low carrying capacity of the Karoo (55 ha/LSU), which covers approximately $70 \%$ of Northern Cape, compared to the carrying capacity of the Bushveld (15 ha/LSU) and Grassland (4 ha/LSU) which cover approximately 86\% and 68\% of Limpopo and Eastern Cape, respectively.

The methane emissions per individual animal were calculated based on the energy requirements as described above. The calculated dry matter intake as a percentage of liveweight is lower than that reported by Smit (2012) for game species. Meissner (1982) indicated that the feed intake of wild ungulates in subtropical regions is less than that of domestic livestock of comparable size. Curtzen et al. (1986) reported annual methane emissions of $34 \mathrm{~kg}, 50 \mathrm{~kg}, 5 \mathrm{~kg}, 26 \mathrm{~kg}$, and $5 \mathrm{~kg}$ for buffalo, giraffe, impala, elephant and 
zebra, respectively. These estimates are considerably lower than those calculated in this study and reported in Table 7. The emission estimates reported by Curtzen et al. (1986) were based on animals with lower liveweights and gross energy intakes than when compared with those reported in Table 7. The $\mathrm{CH}_{4}$ emissions for elephant and zebra were based on emission values of horses, which have similar digestive systems, as 3.5\% of digestible energy intake (Curtzen et al., 1986). The emissions from black wildebeest, tsessebe, blesbok, impala and springbok were based on the equation developed by Howden \& Reyenga (1987) based on respiration chamber experiments on sheep in Australia. Warthog emissions were estimated according to the IPCC (2006) based on pigs in developing countries. All other methane emission estimates for game (giraffe, eland, buffalo, kudu, waterbuck and blue wildebeest) reported in Table 7 were based on an equation developed by Kurihara et al. (1999) based on cattle fed tropical pastures.

Table 6 Estimated methane emissions (Gg/year) and number of large stock units per animal class and province in South Africa

\begin{tabular}{|c|c|c|c|c|c|}
\hline Province & Animal class & $\begin{array}{l}\text { Large stock } \\
\text { units }\end{array}$ & $\begin{array}{c}\text { Enteric } \mathrm{CH}_{4} \\
\text { (Gg/year) }\end{array}$ & $\begin{array}{l}\text { Total } \mathrm{CH}_{4} \\
\text { (Gg/year) }\end{array}$ & $\begin{array}{c}\% \text { contribution } \\
\text { to total } \\
\text { emissions }\end{array}$ \\
\hline \multirow[t]{3}{*}{ Free State } & Grazers & 37019 & 3.74 & & \\
\hline & Mixed feeders & 14824 & 1.17 & 4.98 & 3.78 \\
\hline & Browsers & 1085 & 0.07 & & \\
\hline \multirow[t]{3}{*}{ Gauteng } & Grazers & 23473 & 2.37 & & \\
\hline & Mixed feeders & 9635 & 0.76 & 3.21 & 2.43 \\
\hline & Browsers & 1128 & 0.07 & & \\
\hline \multirow[t]{3}{*}{ Limpopo } & Grazers & 261302 & 26.4 & & \\
\hline & Mixed feeders & 143214 & 11.3 & 43.4 & 32.9 \\
\hline & Browsers & 89243 & 5.7 & & \\
\hline \multirow[t]{3}{*}{ Mpumalanga } & Grazers & 70295 & 7.11 & & \\
\hline & Mixed feeders & 28893 & 2.28 & 9.70 & 7.35 \\
\hline & Browsers & 4871 & 0.31 & & \\
\hline \multirow[t]{3}{*}{ KwaZulu-Natal } & Grazers & 29457 & 2.98 & & \\
\hline & Mixed feeders & 12758 & 1.01 & 4.22 & 3.20 \\
\hline & Browsers & 3743 & 0.24 & & \\
\hline \multirow[t]{3}{*}{ Western Cape } & Grazers & 7470 & 0.76 & & \\
\hline & Mixed feeders & 4095 & 0.32 & 1.12 & 0.85 \\
\hline & Browsers & 655 & 0.04 & & \\
\hline \multirow[t]{3}{*}{ Northern Cape } & Grazers & 152354 & 15.4 & & \\
\hline & Mixed feeders & 63993 & 5.05 & 21 & 15.9 \\
\hline & Browsers & 8552 & 0.55 & & \\
\hline \multirow[t]{3}{*}{ North West } & Grazers & 50464 & 5.10 & & \\
\hline & Mixed feeders & 20066 & 1.58 & 6.92 & 5.25 \\
\hline & Browsers & 13738 & 0.24 & & \\
\hline \multirow[t]{3}{*}{ Eastern Cape } & Grazers & 272337 & 27.5 & & \\
\hline & Mixed feeders & 113110 & 8.92 & 37.3 & 28.3 \\
\hline & Browsers & 126746 & 0.88 & & \\
\hline Total & & 1441504 & 131.9 & 131.9 & 100 \\
\hline
\end{tabular}


Giraffe and eland had comparable daily $\mathrm{CH}_{4}$ emission factors ( $\mathrm{g} \mathrm{CH}_{4} / \mathrm{kg} \mathrm{LW} /$ day) to commercial beef bulls and cows with similar liveweights (LW), according to Du Toit et al. (2013a), with $0.46 \mathrm{~g} \mathrm{CH}_{4} / \mathrm{kg}$ $\mathrm{LW} /$ day compared to $0.42 \mathrm{~g} \mathrm{CH}_{4} / \mathrm{kg} \mathrm{LW} /$ day for giraffe and commercial bulls and $0.51 \mathrm{~g} \mathrm{CH}_{4} / \mathrm{kg} \mathrm{LW} /$ day compared to $0.53 \mathrm{~g} \mathrm{CH}_{4} / \mathrm{kg} \mathrm{LW} /$ day for eland and commercial beef cows, respectively. Buffalo had higher calculated daily $\mathrm{CH}_{4}$ emission factors $\left(0.67 \mathrm{~g} \mathrm{CH}_{4} / \mathrm{kg} \mathrm{LW} /\right.$ day) compared to commercial beef cows $(0.53 \mathrm{~g}$ $\mathrm{CH}_{4} / \mathrm{kg} \mathrm{LW} /$ day) with similar liveweights (Du Toit et al., 2013a). The daily $\mathrm{CH}_{4}$ emission factors of smaller antelope reported in Table 7 were compared to commercial small stock emission factors with similar liveweights according to Du Toit et al. (2013b). Black wildebeest and tsessebe had estimated daily $\mathrm{CH}_{4}$ emission factors ( $\mathrm{g} \mathrm{CH}_{4} / \mathrm{kg} \mathrm{LW} /$ day) that are similar to those of commercial dual purpose breeding rams, but lower emission factors than those of commercial breeding goat bucks with $0.39,0.38,0.37$ and 0.43 for black wildebeest, tsessebe, commercial dual purpose breeding rams and breeding goat bucks, respectively. Impala and springbok had numerically higher estimated daily $\mathrm{CH}_{4}$ emissions factors ( $\mathrm{g} \mathrm{CH}_{4} / \mathrm{kg} \mathrm{LW} /$ day) than commercially farmed goats with similar liveweights as reported by Du Toit et al. (2013b) with 0.50 and 0.48 compared to 0.40 and 0.44 for impala, springbok, young does and kids, respectively.

Table 7 Approximate liveweight (LW), large stock unit (LSU) substitution, diet digestibility, intake (\% of live weight) and methane emissions of selected game species

\begin{tabular}{|c|c|c|c|c|c|c|}
\hline Species & $\begin{array}{c}\text { Weight } \\
(\mathbf{k g})^{\#}\end{array}$ & LSU & $\begin{array}{c}\text { Diet DE* } \\
(\%)\end{array}$ & $\begin{array}{c}\text { Intake } \\
(\% / L W)\end{array}$ & $\begin{array}{c}\mathrm{CH}_{4} \\
\text { (kg/head/year) }\end{array}$ & $\begin{array}{l}\mathrm{CH}_{4} \text { (g/kg } \\
\mathrm{LW} / \text { day) }\end{array}$ \\
\hline Elephant & 2436 & 3.83 & 55 & 1.4 & 81.0 & 0.10 \\
\hline Giraffe & 826 & 1.51 & 65 & 1.4 & 136 & 0.46 \\
\hline Eland & 528 & 1.08 & 65 & 1.6 & 93.7 & 0.51 \\
\hline Buffalo & 466 & 1.08 & 55 & 2.1 & 113 & 0.67 \\
\hline Zebra & 266 & 0.66 & 55 & 2.2 & 13.9 & 0.15 \\
\hline Kudu & 155 & 0.44 & 65 & 2.2 & 31.3 & 0.56 \\
\hline Waterbuck & 150 & 0.41 & 55 & 2.5 & 35.9 & 0.67 \\
\hline $\begin{array}{l}\text { Blue } \\
\text { wildebeest }\end{array}$ & 153 & 0.43 & 75 & 1.8 & 24.8 & 0.44 \\
\hline $\begin{array}{l}\text { Black } \\
\text { wildebeest }\end{array}$ & 106 & 0.30 & 75 & 1.9 & 14.3 & 0.39 \\
\hline Tsessebe & 105 & 0.03 & 65 & 1.8 & 13.8 & 0.38 \\
\hline Blesbok & 62 & 0.19 & 75 & 2.0 & 9.08 & 0.43 \\
\hline Warthog & 59 & 0.21 & 75 & 2.4 & 2.22 & 0.18 \\
\hline Impala & 42 & 0.15 & 75 & 2.4 & 7.40 & 0.50 \\
\hline Springbok & 28 & 0.09 & 75 & 2.2 & 4.72 & 0.48 \\
\hline
\end{tabular}

\footnotetext{
${ }^{\#}$ Animal live weight and daily energy requirements used in intake calculations were sourced from Meissner et al.
} (1983). * DE: feed digestibility.

Tables 8a and 8b reports on the estimated South African privately owned game population according to province, based on the norms presented by ABSA (2003) in Appendices 1A and 1B. The total game population is estimated at 2991370 animals. This is in line with the figure reported by Dry (2011) of 2.5 million animals, but smaller than other figures reported in the literature (NAMC, 2006; ABSA, 2008: Van Rooyen, 2013). 
Annual enteric methane emissions for individual game species reported in Appendix 2 were calculated based on daily intake using the equations of Howden \& Reyenga (1987), Kurihara et al. (1999), and the IPCC (2006), as discussed earlier. For hippopotamus and rhinoceros, the methane emissions were based on the daily methane emissions of elephant of $0.1 \mathrm{~g} \mathrm{CH}_{4} / \mathrm{kg} \mathrm{LW} /$ day. The liveweights of game animals were sourced from Meissner et al. (1983) and Smit (2012). By basing the emission estimates on individual animal populations of approximately 3 million, the total methane emissions for the commercial game industry come to $59.9 \mathrm{Gg}$ per year. This is considerably lower that the emission estimate based on LSUs and stocking rates of $132 \mathrm{Gg}$ reported in Table 6 . The variation in emission estimates is very large when game populations are

Table 8a Estimated game numbers per province based on norms reported by ABSA (2003)

\begin{tabular}{lllllllllllll}
\hline & \multicolumn{10}{c}{ Provinces } \\
\cline { 2 - 5 } & Gt & Mpum & NC & NW & EC & Lim & FS & KZN & WC & Total
\end{tabular}

Low selective grazers

\section{LSU/animal}

$\begin{array}{llrrrrrrrrrr}1.07 & \text { Buffalo } & 288 & 2075 & 862 & 625 & 1732 & 12475 & 439 & 1299 & 26 & 19821 \\ 2.24 & \begin{array}{l}\text { Hippo } \\ 2.75\end{array} & 7 & 49 & 0 & 28 & 84 & 1232 & 0 & 48 & 5 & 1453 \\ & \begin{array}{l}\text { White } \\ \text { Rhino }\end{array} & 112 & 335 & 181 & 224 & 674 & 1574 & 170 & 143 & 9 & 3422 \\ 0.66 & \begin{array}{l}\text { Zebra } \\ \text { (Burchell) }\end{array} & 9418 & 27447 & 2249 & 17151 & 111990 & 124411 & 14206 & 11704 & 841 & 319418 \\ & \begin{array}{l}\text { Zebra } \\ \text { (Cape }\end{array} & 0 & 0 & 16073 & 1536 & 308 & 29 & 106 & 0 & 276 & 18328 \\ \text { mountain) } & & & & & & & & & & & \end{array}$

\section{High selective grazers}

\section{LSU/animal}

$\begin{array}{llrrrrrrrrrr}0.22 & \text { Blesbok } & 14444 & 40255 & 3707 & 23645 & 26836 & 23929 & 26836 & 13759 & 606 & 174017 \\ 0.56 & \text { Gemsbok } & 20 & 36 & 72194 & 4165 & 3515 & 3003 & 470 & 58 & 2942 & 86403 \\ 0.37 & \begin{array}{l}\text { Red } \\ \text { hartebeest }\end{array} & 4464 & 12273 & 37525 & 9814 & 11786 & 32248 & 8216 & 4588 & 1780 & 122694 \\ 0.25 & \text { Reedbuck } & 3325 & 9786 & 816 & 5833 & 7788 & 31718 & 5904 & 3968 & 240 & 69378 \\ 0.64 & \text { Roan } & 17 & 109 & 0 & 74 & 222 & 3100 & 0 & 110 & 12 & 3644 \\ 0.64 & \text { Sable } & 17 & 109 & 0 & 74 & 222 & 3100 & 0 & 110 & 12 & 3644 \\ 0.15 & \text { Springbok } & 21184 & 59040 & 274963 & 49914 & 51540 & 35382 & 41116 & 20180 & 11821 & 565140 \\ 0.38 & \text { Tsessebe } & 233 & 1468 & 0 & 998 & 2975 & 41769 & 0 & 1486 & 168 & 49097 \\ 0.5 & \text { Waterbuck } & 251 & 1581 & 0 & 1073 & 3203 & 44972 & 0 & 1600 & 181 & 52861 \\ 0.46 & \begin{array}{l}\text { Wildebeest } \\ \text { (black) }\end{array} & 15543 & 43317 & 3989 & 25444 & 28878 & 25750 & 28878 & 14806 & 653 & 187258 \\ 0.5 & \begin{array}{l}\text { Wildebeest } \\ \text { (blue) }\end{array} & 782 & 5593 & 80858 & 7917 & 13640 & 144896 & 527 & 5498 & 3844 & 263555 \\ & & & & & & & & & \end{array}$

Gt: Gauteng; Mpum: Mpumalanga; NC: Northern Cape; NW: North West; EC: Eastern Cape; Lim: Limpopo;

FS: Free State; KZN: KwaZulu-Natal; WC: Western Cape. 
used, $50.05 \mathrm{Gg}$ from 2.5 million animals to $336.34 \mathrm{Gg}$ from 18.6 million animals. The type of diet selected by game, the amount of methane produced per unit of feed intake, and variation in daily feed intake are further causes of uncertainty when emission estimates are based on animal populations.

Table 8b Estimated game numbers per province based on norms reported by ABSA (2003)

\begin{tabular}{|c|c|c|c|c|c|c|c|c|c|c|c|}
\hline \multirow{2}{*}{\multicolumn{2}{|c|}{ Animal Species }} & \multicolumn{9}{|c|}{ Provinces } & \multirow{2}{*}{ Total } \\
\hline & & \multirow[t]{2}{*}{ Gt } & \multirow[t]{2}{*}{ Mpum } & \multirow[t]{2}{*}{ NC } & \multirow[t]{2}{*}{ NW } & \multirow[t]{2}{*}{ EC } & \multirow[t]{2}{*}{ Lim } & \multirow[t]{2}{*}{ FS } & \multirow[t]{2}{*}{ KZN } & \multirow[t]{2}{*}{ WC } & \\
\hline \multicolumn{3}{|c|}{ Mixed feeders } & & & & & & & & & \\
\hline \multicolumn{12}{|c|}{ LSU/animal } \\
\hline 0.09 & Duiker & 2223 & 6660 & 19610 & 4888 & 7999 & 44604 & 3797 & 3146 & 1323 & 94250 \\
\hline 1.08 & Eland & 7922 & 22061 & 46592 & 14226 & 18789 & 27678 & 14828 & 7795 & 3113 & 163004 \\
\hline 5 & Elephant & 15 & 94 & 0 & 66 & 198 & 2754 & 0 & 96 & 11 & 3236 \\
\hline 0.2 & Impala & 1292 & 9382 & 25000 & 8630 & 16486 & 240164 & 167 & 9190 & 933 & 311244 \\
\hline 0.23 & Nyala & 0 & 1023 & 0 & 0 & 0 & 7093 & 0 & 783 & 0 & 8899 \\
\hline 0.38 & Ostrich & 97 & 772 & 9857 & 940 & 1707 & 18525 & 64 & 742 & 490 & 33194 \\
\hline 0.25 & $\begin{array}{l}\text { Reedbuck } \\
\text { (mountain) }\end{array}$ & 1156 & 3467 & 3595 & 2539 & 3114 & 17188 & 2006 & 1531 & 109 & 34705 \\
\hline 0.25 & Warthog & 148 & 1594 & 9057 & 1756 & 1884 & 31080 & 61 & 1450 & 107 & 47137 \\
\hline
\end{tabular}

\section{Browse}

\section{LSU/animal}

\begin{tabular}{|c|c|c|c|c|c|c|c|c|c|c|c|}
\hline 0.13 & Bushbuck & 114 & 954 & 0 & 486 & 1449 & 22001 & 0 & 907 & 82 & 25993 \\
\hline 1.58 & Giraffe & 156 & 1072 & 269 & 699 & 1987 & 28537 & 2 & 1063 & 112 & 33897 \\
\hline 0.07 & Klipspringer & 1160 & 3701 & 8108 & 2503 & 2954 & 15944 & 1736 & 1662 & 428 & 38196 \\
\hline 0.54 & Kudu & 556 & 2386 & 8154 & 2407 & 4516 & 48619 & 933 & 1911 & 346 & 69828 \\
\hline 0.13 & $\begin{array}{l}\text { Rhebuck } \\
\text { (grey) }\end{array}$ & 1800 & 5654 & 977 & 3314 & 3947 & 24798 & 2501 & 2527 & 153 & 45671 \\
\hline 1.65 & $\begin{array}{l}\text { Rhino } \\
\text { (Black) }\end{array}$ & 9 & 56 & 129 & 54 & 114 & 1604 & 1 & 57 & 6 & 2030 \\
\hline 0.06 & Steenbuck & 3371 & 10258 & 46959 & 6998 & 10842 & 49285 & 4680 & 4318 & 3245 & 139953 \\
\hline Tota & + b) & 90124 & 272607 & 671724 & 198021 & 341379 & 1109462 & 157644 & 116533 & 33880 & 2991370 \\
\hline
\end{tabular}

Gt: Gauteng; Mpum: Mpumalanga; NC: Northern Cape; NW: North West; EC: Eastern Cape; Lim: Limpopo; FS: Free State; KZN: KwaZulu-Natal; WC: Western Cape.

The $\mathrm{CH}_{4}$ emissions estimates per species are reported in Appendix 2. As $\mathrm{CH}_{4}$ emissions originating from manure of game are very low, it is not reported in the table in Appendix 2. Although the $\mathrm{N}_{2} \mathrm{O}$ emitted from soil through the metabolism of manure and urine is not reported under livestock emissions according to the IPCC (2006) good practice guidelines, it is mentioned to provide a more complete scenario of emissions associated with game on privately owned land. Nitrogen in faecal matter is primarily in an organic form and must first be mineralized before it becomes a source of $\mathrm{N}_{2} \mathrm{O}$. The mineralization process occurs at significant 
rates in higher rainfall regions. However, the decay of faeces in drier areas is much slower, with faeces remaining largely intact for months to years (ANIR, 2009). The $\mathrm{N}_{2} \mathrm{O}$ emissions from faeces and urine voided in rangeland were estimated at $0.39 \mathrm{Gg} \mathrm{N}_{2} \mathrm{O}$ /year on a national scale using emission factors of 0.005 and $0.004 \mathrm{Gg} \mathrm{N} \mathrm{N}_{2} \mathrm{O}-\mathrm{N} / \mathrm{Gg} \mathrm{N}$ for faeces and urine, respectively, according to the ANIR (2009). Penttilä et al. (2013) reported that dung beetles could potentially increase GHG emissions from faeces voided on rangeland or veld, mainly due to increased $\mathrm{N}_{2} \mathrm{O}$ emissions. The possible effect of dung beetles is noted but not included in the present inventory due to insufficient data under South African conditions. The Limpopo province had the largest emissions originating from game followed by Northern Cape and Eastern Cape provinces.

\section{Conclusion}

Game was not included in previous inventories, but was identified as a key $\mathrm{CH}_{4}$ emissions source in the present inventory, contributing $132 \mathrm{Gg}$ of $\mathrm{CH}_{4}$. Nitrous oxide emissions from rangeland soils originating from faecal matter were estimated at $0.39 \mathrm{Gg} \mathrm{N}_{2} \mathrm{O}$ /year. There is a great deal of uncertainty in the estimation of GHG emissions from game on game farms. To base the $\mathrm{CH}_{4}$ emission estimation on the ecological carrying capacity of commercial game farms remains the soundest approach, as the variations in game population numbers and intake estimations are extremely large. Multiple sources agreed on the figure for the surface area under private game in South Africa of 20.5 million hectares and this appears the only justifiable basis for the emissions estimation.

\section{Acknowledgement}

This work is based on the research supported wholly by the National Research Foundation of South Africa and the RMRD SA.

\section{References}

ABSA, 2003. Game farm profitability in Southern Africa. The SA financial sector forum. Rivonia, South Africa.

ABSA, 2008. Game farm profitability in Southern Africa. The SA financial sector forum. Rivonia, South Africa.

ANIR, 2009. Australian national greenhouse accounts: National inventory report. Department of climate change and energy efficiency, Australian National Inventory Report, Commonwealth of Australia, Canberra, ACT.

Blignaut, J.N., Chitiga-Habugu, H.R. \& Habugu, R.M., 2005.Constructing a GHG inventory using energy balances: The case of South Africa, 1998. J. Energy S. Afr. 16, 21-32.

Bothma, J.duP. \& Van Rooyen, N., 2004. Using diet and plant resources to set wildlife stocking densities in African savannas. Wildlife Society bulletin, 32 (3), 840-841.

Bothma, J.duP., 1995. Introduction in: Game ranch management, $2^{\text {nd }}$ ed. Ed: Bothma, J.duP., J.L. van Schaik, Hatfield, Pretoria, South Africa.

Bredenkamp, G., Granger, J.E. \& Van Rooyen, N., 1996. Delimination of vegetation types. In: Vegetation of Southern Africa, Lesotho and Swaziland. Eds: Low, A.B. \& Robelo, A.G., Department of Environmental Affairs and Tourism, Pretoria, South Africa.

Carruthers, J., 2004. "Wilding the farm or farming the wild"? The evolution of scientific game ranching in South Africa from the 1960s to the present. Trans. Royal Soc. S. Afr. 63 (2) 160-181.

Cousins, J.A., Sadler, J.P. \& Evans, J., 2008. Exploring the role of private wildlife ranching as a conservation tool in South Africa: Stakeholder perspective. Ecology and Society 13 (2), 43-51.

Curtzen, P.J., Aselmann, I. \& Seiler, W., 1986. Methane production by domestic animals, wild ruminants, other herbivorous fauna, and humans. Tellus 38B, 271-284.

Dry, G.C., 2011. Commercial wildlife ranching's contribution to a resource efficient. Low carbon, proemployment green economy. Presentation at the $7^{\text {th }}$ International Wildlife Ranching Symposium, Kimberley, October 2011. South Africa.

Du Toit, J.G., 2007. Report: Role of the private sector in the wildlife industry. Tshwane, Wildlife Ranching SA/Du Toit Wilddienste, South Africa. 87 pp.

Du Toit, C.J.L., Meissner, H.H. \& Van Niekerk, W.A., 2013a. Direct methane and nitrous oxide emissions of South African dairy and beef cattle. S. Afr. J. Anim. Sci. 43, 320-339. 
Du Toit, C.J.L., Van Niekerk, W.A. \& Meissner, H.H., 2013b. Direct greenhouse gas emissions of South African small stock sectors. S. Afr. J. Anim. Sci. 43, 340-361.

Eloff, T., 1996. Farming with the future. SA Game \& Hunt. 2 (3), 21-24.

Eloff, T., 2002. The economic realities of the game industry in South Africa. In: Sustainable utilization in practice. Eds: Ebedes, H., Reilly, B., Van Hoven, W. \& Penzhorn, B., Proceedings of the $5^{\text {th }}$ International Wildlife Ranching Symposium, 2002, Pretoria, South Africa.

Furstenburg, D., 2011. Optimizing game production in a new era: The road to financial success. Agricultural Research Council: Range and Forage Institute, Grootfontein, Middelburg, South Africa. http://gadi.agric.za/articles/Furstenburg_D/optimizing-game-production.php?

Gonzalez-Avalos, E. \& Ruiz-Suarez, L.G., 2001. Methane emission factors from cattle manure in Mexico. Biosecure Technology 80 (1), 63-71.

Hofmann, R.R., 1973. The ruminant stomach. East African monographs. Biology 2, 1-354.

Howden, S.M. \& Reyenga, P.J., 1987. Methane emissions from Australian livestock: Implication of the Kyoto protocol. Aust. J. Agric. Res. 50, 1285-1291.

IPCC, 2006. IPCC guidelines for National Greenhouse Gas Inventories, Prepared by the National Greenhouse Gas Inventories Programme. Eds: Eggleston, H.S., Buendia, L., Miwa, K., Ngara, T. \& Tanabe, K., Published: IGES, Japan.

Kurihara, M., Magner, T., Hunter, R.A. \& McCrabb, G.J., 1999. Methane production and energy partition of cattle in the tropics. Br. J. Nutr. 81, 227-234.

Meissner, H.H., 1982. Theory and application of a method to calculate forage intake of wild southern African ungulates for purpose of estimating carrying capacity. S. Afr. J. Wildl. Res. 12 (2), 41-47.

Meissner, H.H., Hofmeyr, H.S., Van Rensburg, W.J.J. \& Pienaar, J.P., 1983. Classification of livestock for realistic prediction of substitution values in term of a biologically defined large stock unit. Technical Communication, Department of Agriculture, Republic of South Africa.

NAMC, 2006. Report on the investigation to identify problems for sustainable growth and development in South African wildlife ranching. National Agricultural Marketing Council, Report No 2006-03, South Africa.

Nell, D.D’A., 2003. The development of wildlife utilization in South Africa and Kenya, 1950 - 1990. DPhil thesis, University of Oxford, U.K.

Otter, L., 2010. The South African agricultural GHG inventory for 2004. Department of Agriculture, Forestry and Fisheries, South Africa.

Penttilä, A., Slade, E.M., Simojoki, A., Riutta, T., Minkkinen, K. \& Roslin, T., 2013. Quantifying beetlemediated effects on gas fluxes from dung pats. PloS One 8 (8), 1-7.

Smit, G.N., 2012. Grazing capacity - game. Calculation of grazing capacity and browse capacity for game species. Department of Animal, Wildlife and Grassland Sciences, University of the Free State, Bloemfontein, South Africa.

Van der Merwe, P. \& Saayman, M., 2003. Determining the economic value of game farm tourism. Koedoe 46 (2), 103-112.

Van der Waal, C. \& Dekker, B., 2000. Game ranching in the Northern Province of South Africa. S. Afr. J Wildl. Res. 30 (4), 151-156.

Van Rooyen, L., 2013. Game ranches unite to influence policy. Farmers Weekly, 9 April 2013, South Africa. 


\section{Appendix}

Appendix 1A Minimum herd size and relative distribution of animal species per ecological region for larger farms (ABSA, 2003)

\begin{tabular}{|c|c|c|c|c|c|c|}
\hline \multirow[b]{2}{*}{ Animal species } & \multicolumn{6}{|c|}{ Relative distribution of animal species as a \% of LSU* } \\
\hline & $\begin{array}{l}\text { Min. social } \\
\text { herd size }\end{array}$ & Grassland & Lowveld & Bushveld & Kalahari & Karoo \\
\hline Low selective grazers & & $20 \%$ & $25 \%$ & $20 \%$ & $10 \%$ & $2 \%$ \\
\hline Buffalo & 15 & 15 & 50 & 15 & 30 & \\
\hline Hippo & 15 & & 10 & 10 & & \\
\hline White Rhino & 5 & 15 & 10 & 15 & 15 & \\
\hline Zebra (Burchell) & 5 & 70 & 30 & 60 & & \\
\hline Zebra (Cape mountain) & 10 & & & & 55 & 100 \\
\hline High selective grazers & & $50 \%$ & $30 \%$ & $30 \%$ & $65 \%$ & $60 \%$ \\
\hline Blesbok & 12 & 20 & & & & \\
\hline Gemsbok & 12 & & & 5 & 30 & 30 \\
\hline Red hartebeest & 12 & 10 & & 5 & 10 & 10 \\
\hline Reedbuck & 8 & 5 & 5 & 5 & & \\
\hline Roan & 12 & & 5 & 5 & & \\
\hline Sable & 12 & & 5 & 5 & & \\
\hline Springbok & 15 & 20 & & & 30 & 30 \\
\hline Tsessebe & 12 & & 5 & 5 & & \\
\hline Waterbuck & 12 & & 10 & 10 & & \\
\hline Wildebeest (black) & 12 & 45 & & & & \\
\hline Wildebeest (blue) & 12 & & 70 & 60 & 30 & 30 \\
\hline Mixed feeders & & $28 \%$ & $25 \%$ & $30 \%$ & $20 \%$ & $35 \%$ \\
\hline Duiker & 6 & 2 & 3 & 3 & 3 & 3 \\
\hline Eland & 12 & 95 & 10 & 14 & 54 & 92 \\
\hline Elephant & 12 & & 40 & 35 & & \\
\hline Impala & 15 & & 30 & 35 & 30 & \\
\hline Nyala & 12 & & 5 & & & \\
\hline Ostrich & 6 & & 4 & 5 & 5 & 5 \\
\hline Reedbuck (mountain) & 8 & 3 & 3 & 3 & 3 & \\
\hline Warthog & 12 & & 5 & 5 & 5 & \\
\hline Browsers & & $2 \%$ & $20 \%$ & $20 \%$ & $5 \%$ & $3 \%$ \\
\hline Bushbuck & 8 & & 3 & 3 & & \\
\hline Giraffe & 8 & & 60 & 50 & 30 & \\
\hline Klipspringer & 4 & 5 & 1 & 1 & 5 & 5 \\
\hline Kudu & 12 & 80 & 20 & 30 & 40 & 90 \\
\hline Rhebuck (grey) & 8 & 10 & 3 & 3 & 5 & \\
\hline Rhino (black) & 5 & & 10 & 10 & 15 & \\
\hline Steenbok & 5 & 5 & 3 & 3 & 5 & 5 \\
\hline
\end{tabular}


Appendix 1B Minimum herd size and relative distribution of animal species per ecological region for smaller farms (ABSA, 2003)

\begin{tabular}{|c|c|c|c|c|c|c|}
\hline & & Relative d & tribution & animal spe & ies as a $\%$ & f LSU* \\
\hline Animal species & $\begin{array}{l}\text { Min. social } \\
\text { herd size }\end{array}$ & Grassland & Lowveld & Bushveld & Kalahari & Karoo \\
\hline Low selective grazers & & $20 \%$ & $25 \%$ & $20 \%$ & $10 \%$ & $2 \%$ \\
\hline Buffalo & 15 & & 50 & & & \\
\hline Zebra (Burchell) & 5 & 100 & 50 & 100 & & \\
\hline Zebra (Cape mountain) & 10 & & & & 100 & 100 \\
\hline High selective grazers & & $50 \%$ & $30 \%$ & $30 \%$ & $65 \%$ & $60 \%$ \\
\hline Blesbok & 12 & 20 & & & & \\
\hline Gemsbok & 12 & & & & 30 & 30 \\
\hline Red hartebeest & 12 & 10 & & 10 & 10 & 10 \\
\hline Reedbuck & 8 & 5 & 5 & 5 & & \\
\hline Springbok & 15 & 20 & & & 30 & 30 \\
\hline Tsessebe & 12 & & 15 & 15 & & \\
\hline Waterbuck & 12 & & 20 & 20 & & \\
\hline Wildebeest (black) & 12 & 45 & & & & \\
\hline Wildebeest (blue) & 12 & & 60 & 50 & 30 & 30 \\
\hline Mixed feeders & & $28 \%$ & $25 \%$ & $30 \%$ & $20 \%$ & $35 \%$ \\
\hline Duiker & 6 & 2 & 2 & 2 & 2 & 3 \\
\hline Eland & 12 & 95 & & & 43 & 92 \\
\hline Impala & 15 & & 60 & 70 & 25 & \\
\hline Nyala & 12 & & 10 & & & \\
\hline Ostrich & 6 & & 10 & 10 & 10 & 5 \\
\hline Reedbuck (mountain) & 8 & 3 & 3 & 3 & 5 & \\
\hline Warthog & 12 & & 15 & 15 & 15 & \\
\hline Browsers & & $2 \%$ & $20 \%$ & $20 \%$ & $5 \%$ & $3 \%$ \\
\hline Bushbuck & 8 & & 5 & 5 & & \\
\hline Giraffe & 8 & & 55 & 50 & & \\
\hline Klipspringer & 4 & 15 & 2 & 2 & 5 & 10 \\
\hline Kudu & 12 & & 30 & 35 & 85 & \\
\hline Rhebuck (grey) & 8 & 45 & 5 & 5 & & \\
\hline Steenbok & 5 & 40 & 3 & 3 & 10 & 90 \\
\hline
\end{tabular}


Appendix 2A Breakdown of animal species, energy requirements, diet characteristics, intake and annual enteric methane emissions

\begin{tabular}{|c|c|c|c|c|c|c|c|c|}
\hline \multirow[b]{2}{*}{ Animal Species } & \multicolumn{2}{|c|}{$\begin{array}{c}\text { Animal } \\
\text { characteristics }\end{array}$} & \multirow[b]{2}{*}{ LSU } & \multicolumn{2}{|c|}{$\begin{array}{c}\text { Diet } \\
\text { characteristics } \\
\end{array}$} & \multirow{2}{*}{$\begin{array}{l}\text { Intake (kg } \\
\text { DM/day) }\end{array}$} & \multirow{2}{*}{$\begin{array}{c}\text { Intake } \\
(\% / L W)\end{array}$} & \multirow{2}{*}{$\begin{array}{c}\mathrm{CH}_{4} \\
\mathrm{~kg} / \mathrm{h} / \text { year }\end{array}$} \\
\hline & $\begin{array}{c}\text { Weight } \\
\text { (kg) }\end{array}$ & $\begin{array}{c}\text { ME } \\
\begin{array}{c}\text { requirements } \\
\text { (MJ/day) }\end{array} \\
\end{array}$ & & $\begin{array}{c}\text { Diet } \\
\text { DE\% }\end{array}$ & $\begin{array}{c}\mathrm{ME} \\
\mathrm{MJ} / \mathrm{kg}\end{array}$ & & & \\
\hline \multicolumn{9}{|l|}{ Elephant } \\
\hline $\begin{array}{l}\text { Calf } \\
(5 \text { years })\end{array}$ & 850 & 84.8 & 1.13 & 55 & 8.3 & 10.2 & 1.2 & 23.9 \\
\hline $\begin{array}{l}\text { Cow, dry } \\
\text { (15 years) }\end{array}$ & 1850 & 285 & 3.80 & 55 & 8.3 & 34.3 & 1.9 & 80.4 \\
\hline $\begin{array}{l}\text { Cow, dry } \\
\text { (50 years) }\end{array}$ & 3300 & 291 & 3.88 & 55 & 8.3 & 35.1 & 1.1 & 82.1 \\
\hline $\begin{array}{l}\text { Cow with calf } \\
\text { (15 years) }\end{array}$ & 1850 & 362 & 4.83 & 55 & 8.3 & 43.6 & 2.4 & 102.1 \\
\hline $\begin{array}{l}\text { Cow with calf } \\
\text { ( } 50 \text { years) }\end{array}$ & 3300 & 375 & 5.00 & 55 & 8.3 & 45.2 & 1.4 & 105.8 \\
\hline $\begin{array}{l}\text { Bull } \\
\text { (15 years) }\end{array}$ & 2200 & 303 & 4.04 & 55 & 8.3 & 36.5 & 1.7 & 85.5 \\
\hline $\begin{array}{l}\text { Bull } \\
\text { (50 years) }\end{array}$ & 3700 & 310 & 4.13 & 55 & 8.3 & 37.3 & 1.0 & 87.5 \\
\hline Average & 2435.7 & 287.3 & 3.83 & 55 & 8.3 & 34.6 & 1.4 & 81.0 \\
\hline \multicolumn{9}{|l|}{ Giraffe } \\
\hline $\begin{array}{l}\text { Calf } \\
\text { (9 months) }\end{array}$ & 390 & 57.8 & 0.77 & 65 & 9.81 & 5.9 & 1.5 & 63.8 \\
\hline $\begin{array}{l}\text { Cow, dry } \\
\text { ( } 5 \text { years) }\end{array}$ & 770 & 111.0 & 1.48 & 65 & 9.81 & 11.3 & 1.5 & 132.9 \\
\hline $\begin{array}{l}\text { Cow, dry } \\
\text { (10 years) }\end{array}$ & 850 & 101.0 & 1.35 & 65 & 9.81 & 10.3 & 1.2 & 119.9 \\
\hline $\begin{array}{l}\text { Cow with calf } \\
\text { ( } 5 \text { years) }\end{array}$ & 770 & 139.0 & 1.85 & 65 & 9.81 & 14.2 & 1.8 & 169.3 \\
\hline $\begin{array}{l}\text { Cow with calf } \\
\text { (10 years) }\end{array}$ & 850 & 130.0 & 1.73 & 65 & 9.81 & 13.3 & 1.6 & 157.6 \\
\hline Bull (5 years) & 960 & 126.0 & 1.68 & 65 & 9.81 & 12.8 & 1.3 & 152.4 \\
\hline Bull (6 years) & 1190 & 127.0 & 1.69 & 65 & 9.81 & 12.9 & 1.1 & 153.7 \\
\hline Average & 825.7 & 113.1 & 1.51 & 65 & 9.81 & 11.5 & 1.4 & 135.6 \\
\hline \multicolumn{9}{|l|}{ Eland } \\
\hline $\begin{array}{l}\text { Calf } \\
\text { (8 months) }\end{array}$ & 200 & 38.9 & 0.52 & 65 & 9.81 & 4.0 & 2.0 & 39.3 \\
\hline $\begin{array}{l}\text { Cow dry } \\
\text { (3 years) }\end{array}$ & 460 & 75.5 & 1.01 & 65 & 9.81 & 7.7 & 1.7 & 86.8 \\
\hline $\begin{array}{l}\text { Cow dry } \\
\text { (6 years) }\end{array}$ & 500 & 72.1 & 0.96 & 65 & 9.81 & 7.3 & 1.5 & 82.4 \\
\hline $\begin{array}{l}\text { Cow with calf } \\
\text { ( } 3 \text { years) }\end{array}$ & 460 & 96.6 & 1.29 & 65 & 9.81 & 9.8 & 2.1 & 114.2 \\
\hline $\begin{array}{l}\text { Cow with calf } \\
\text { (6 years) }\end{array}$ & 500 & 87.1 & 1.16 & 65 & 9.81 & 8.9 & 1.8 & 101.9 \\
\hline Bull (3 years) & 760 & 99.5 & 1.33 & 65 & 9.81 & 10.1 & 1.3 & 118.0 \\
\hline Bull (6 years) & 815 & 96.0 & 1.28 & 65 & 9.81 & 9.8 & 1.2 & 113.4 \\
\hline Average & 528 & 80.8 & 1.1 & 65 & 9.81 & 8.2 & 1.6 & 93.7 \\
\hline
\end{tabular}

LSU: large stock unit; ME: metabolizable energy; DE: digestibility; DM: dry matter; LW: liveweight;

$\mathrm{CH}_{4}$ : methane; $\mathrm{kg} / \mathrm{h} /$ year $=\mathrm{kg} / \mathrm{head} /$ year. 
Appendix 2B Breakdown of animal species, energy requirements, diet characteristics, intake and annual enteric methane emissions

\begin{tabular}{|c|c|c|c|c|c|c|c|c|}
\hline \multirow[b]{2}{*}{ Animal species } & \multicolumn{2}{|c|}{$\begin{array}{c}\text { Animal } \\
\text { characteristics }\end{array}$} & \multirow[b]{2}{*}{ LSU } & \multicolumn{2}{|c|}{$\begin{array}{c}\text { Diet } \\
\text { characteristics }\end{array}$} & \multirow{2}{*}{$\begin{array}{l}\text { Intake(kg } \\
\text { DM/day) }\end{array}$} & \multirow{2}{*}{$\begin{array}{l}\text { Intake } \\
(\% / L W)\end{array}$} & \multirow{2}{*}{$\begin{array}{c}\mathrm{CH}_{4} \\
\text { (kg/h/year) }\end{array}$} \\
\hline & $\begin{array}{l}\text { Weight } \\
\text { (kg) }\end{array}$ & $\begin{array}{c}\text { ME } \\
\text { requirements } \\
\text { (MJ/day) }\end{array}$ & & $\begin{array}{c}\text { Diet } \\
\text { DE\% }\end{array}$ & $\begin{array}{c}\text { ME } \\
(\mathrm{MJ} / \mathrm{kg})\end{array}$ & & & \\
\hline \multicolumn{9}{|l|}{ Buffalo } \\
\hline $\begin{array}{l}\text { Calf } \\
\text { (8 months) }\end{array}$ & 145 & 31.8 & 0.42 & 55 & 8.3 & 3.8 & 2.6 & 37.6 \\
\hline $\begin{array}{l}\text { Cow dry } \\
\text { (4 years) }\end{array}$ & 460 & 79.1 & 1.05 & 55 & 8.3 & 9.5 & 2.1 & 110.2 \\
\hline $\begin{array}{l}\text { Cow dry } \\
\text { (10 years) }\end{array}$ & 530 & 76.4 & 1.02 & 55 & 8.3 & 9.2 & 1.7 & 106.0 \\
\hline $\begin{array}{l}\text { Cow with calf } \\
\text { ( } 4 \text { years) }\end{array}$ & 460 & 101.0 & 1.35 & 55 & 8.3 & 12.2 & 2.6 & 143.2 \\
\hline $\begin{array}{l}\text { Cow with calf } \\
\text { (10 years) }\end{array}$ & 530 & 99.3 & 1.32 & 55 & 8.3 & 12.0 & 2.3 & 141.2 \\
\hline Bull (4 years) & 500 & 89.6 & 1.19 & 55 & 8.3 & 10.8 & 2.2 & 126.3 \\
\hline Bull (10 years) & 640 & 87.7 & 1.17 & 55 & 8.3 & 10.6 & 1.7 & 123.4 \\
\hline Average & 466.4 & 80.7 & 1.08 & 55 & 8.3 & 9.7 & 2.1 & 112.6 \\
\hline \multicolumn{9}{|l|}{ Zebra } \\
\hline $\begin{array}{l}\text { Foal } \\
\text { (5 months) }\end{array}$ & 95 & 24.6 & 0.33 & 55 & 8.3 & 3.0 & 3.1 & 6.9 \\
\hline $\begin{array}{l}\text { Mare dry } \\
\text { (4 years) }\end{array}$ & 270 & 48.9 & 0.65 & 55 & 8.3 & 5.9 & 2.2 & 13.8 \\
\hline $\begin{array}{l}\text { Mare dry } \\
\text { (7 years) }\end{array}$ & 290 & 45.0 & 0.60 & 55 & 8.3 & 5.4 & 1.9 & 12.7 \\
\hline $\begin{array}{l}\text { Mare with foal } \\
\text { (4 years) }\end{array}$ & 270 & 61.0 & 0.81 & 55 & 8.3 & 7.3 & 2.7 & 17.2 \\
\hline $\begin{array}{l}\text { Mare with foal } \\
\text { (7 years) }\end{array}$ & 290 & 58.9 & 0.79 & 55 & 8.3 & 7.1 & 2.4 & 16.6 \\
\hline $\begin{array}{l}\text { Stallion } \\
\text { (4 years) }\end{array}$ & 310 & 54.0 & 0.72 & 55 & 8.3 & 6.5 & 2.1 & 15.2 \\
\hline $\begin{array}{l}\text { Stallion } \\
\text { ( } 7 \text { years) }\end{array}$ & 335 & 52.1 & 0.69 & 55 & 8.3 & 6.3 & 1.9 & 14.7 \\
\hline Average & 265.7 & 49.2 & 0.66 & 55 & 8.3 & 5.9 & 2.2 & 13.9 \\
\hline \multicolumn{9}{|l|}{ Kudu } \\
\hline $\begin{array}{l}\text { Calf } \\
\text { (6 months) }\end{array}$ & 55 & 15.8 & 0.21 & 65 & 9.81 & 1.6 & 2.9 & 9.3 \\
\hline $\begin{array}{l}\text { Cow dry } \\
\text { (3 years) }\end{array}$ & 125 & 27.9 & 0.37 & 65 & 9.81 & 2.8 & 2.3 & 25.0 \\
\hline $\begin{array}{l}\text { Cow dry } \\
\text { ( } 5 \text { years) }\end{array}$ & 160 & 29.8 & 0.40 & 65 & 9.81 & 3.0 & 1.9 & 27.5 \\
\hline $\begin{array}{l}\text { Cow with calf } \\
\text { ( } 3 \text { years) }\end{array}$ & 125 & 34.9 & 0.47 & 65 & 9.81 & 3.6 & 2.8 & 34.1 \\
\hline $\begin{array}{l}\text { Cow with calf } \\
\text { (5 years) }\end{array}$ & 160 & 38.7 & 0.52 & 65 & 9.81 & 3.9 & 2.5 & 39.0 \\
\hline Bull (3 years) & 220 & 42.1 & 0.56 & 65 & 9.81 & 4.3 & 2.0 & 43.4 \\
\hline Bull (5 years) & 240 & 39.9 & 0.53 & 65 & 9.81 & 4.1 & 1.7 & 40.6 \\
\hline Average & 155 & 32.7 & 0.44 & 65 & 9.81 & 3.3 & 2.2 & 31.3 \\
\hline
\end{tabular}

LSU: large stock unit; ME: metabolizable energy; DE: digestibility; DM: dry matter; LW: liveweight;

$\mathrm{CH}_{4}$ : methane; $\mathrm{kg} / \mathrm{h} /$ year $=\mathrm{kg} / \mathrm{head} / \mathrm{year}$. 
Appendix 2C Breakdown of animal species, energy requirements, diet characteristics, intake and annual enteric methane emissions

\begin{tabular}{|c|c|c|c|c|c|c|c|c|}
\hline \multirow[b]{2}{*}{ Animal species } & \multicolumn{2}{|c|}{$\begin{array}{c}\text { Animal } \\
\text { characteristics }\end{array}$} & \multirow[b]{2}{*}{ LSU } & \multicolumn{2}{|c|}{$\begin{array}{c}\text { Diet } \\
\text { characteristics }\end{array}$} & \multirow{2}{*}{$\begin{array}{l}\text { Intake(kg } \\
\text { DM/day) }\end{array}$} & \multirow{2}{*}{$\begin{array}{c}\text { Intake } \\
(\% / L W)\end{array}$} & \multirow{2}{*}{$\underset{\text { (kg/h/day) }}{\mathrm{CH}_{4}}$} \\
\hline & $\begin{array}{l}\text { Weight } \\
\text { (kg) }\end{array}$ & $\begin{array}{c}\text { ME } \\
\text { requirements } \\
\text { (MJ/day) }\end{array}$ & & $\begin{array}{l}\text { Diet } \\
\text { DE\% }\end{array}$ & $\begin{array}{c}\mathrm{ME} \\
\mathrm{MJ} / \mathrm{kg}\end{array}$ & & & \\
\hline \multicolumn{9}{|l|}{ Waterbuck } \\
\hline $\begin{array}{l}\text { Lamb } \\
\text { (5 months) }\end{array}$ & 47 & 15.0 & 0.20 & 55 & 8.3 & 1.8 & 3.8 & 11.8 \\
\hline $\begin{array}{l}\text { Ewe dry } \\
\text { (3 years) }\end{array}$ & 130 & 27.6 & 0.37 & 55 & 8.3 & 3.3 & 2.6 & 31.1 \\
\hline $\begin{array}{l}\text { Ewe dry } \\
\text { (5 years) }\end{array}$ & 160 & 28.1 & 0.37 & 55 & 8.3 & 3.4 & 2.1 & 31.9 \\
\hline $\begin{array}{l}\text { Ewe with lamb } \\
\text { (3 years) }\end{array}$ & 130 & 34.6 & 0.46 & 55 & 8.3 & 4.2 & 3.2 & 41.9 \\
\hline $\begin{array}{l}\text { Ewe with lamb } \\
\text { ( } 5 \text { years) }\end{array}$ & 160 & 36.6 & 0.49 & 55 & 8.3 & 4.4 & 2.8 & 44.9 \\
\hline Ram (3 years) & 195 & 37.3 & 0.50 & 55 & 8.3 & 4.5 & 2.3 & 46.0 \\
\hline Ram (5 years) & 225 & 35.6 & 0.47 & 55 & 8.3 & 4.3 & 1.9 & 43.4 \\
\hline Average & 149.6 & 30.7 & 0.41 & 55 & 8.3 & 3.7 & 2.5 & 35.9 \\
\hline \multicolumn{9}{|l|}{ Blue wildebeest } \\
\hline $\begin{array}{l}\text { Calf } \\
\text { (4 months) }\end{array}$ & 51 & 15.6 & 0.21 & 75 & 11.32 & 1.4 & 2.7 & 6.3 \\
\hline $\begin{array}{l}\text { Cow dry } \\
\text { (3 years) }\end{array}$ & 145 & 29.8 & 0.40 & 75 & 11.32 & 2.6 & 1.8 & 22.3 \\
\hline $\begin{array}{l}\text { Cow dry } \\
\text { (5 years) }\end{array}$ & 160 & 29.4 & 0.39 & 75 & 11.32 & 2.6 & 1.6 & 21.8 \\
\hline $\begin{array}{l}\text { Cow with calf } \\
\text { (3 years) }\end{array}$ & 145 & 37.3 & 0.50 & 75 & 11.32 & 3.3 & 2.3 & 30.7 \\
\hline $\begin{array}{l}\text { Cow with calf } \\
\text { (5 years) }\end{array}$ & 160 & 38.3 & 0.51 & 75 & 11.32 & 3.4 & 2.1 & 31.9 \\
\hline Bull (3 years) & 195 & 37.2 & 0.50 & 75 & 11.32 & 3.3 & 1.7 & 30.6 \\
\hline Bull (5 years) & 215 & 36.3 & 0.48 & 75 & 11.32 & 3.2 & 1.5 & 29.6 \\
\hline Average & 153 & 32.0 & 0.43 & 75 & 11.32 & 2.8 & 1.8 & 24.8 \\
\hline \multicolumn{9}{|l|}{ Black wildebeest } \\
\hline $\begin{array}{l}\text { Calf } \\
\text { (4 months) }\end{array}$ & 40 & 12.5 & 0.17 & 75 & 11.32 & 1.1 & 2.8 & 8.2 \\
\hline $\begin{array}{l}\text { Cow dry } \\
\text { (3 years) }\end{array}$ & 105 & 20.3 & 0.27 & 75 & 11.32 & 1.8 & 1.7 & 12.9 \\
\hline $\begin{array}{l}\text { Cow dry } \\
\text { (5 years) }\end{array}$ & 115 & 21.6 & 0.29 & 75 & 11.32 & 1.9 & 1.7 & 13.7 \\
\hline $\begin{array}{l}\text { Cow with calf } \\
\text { (3 years) }\end{array}$ & 105 & 25.4 & 0.34 & 75 & 11.32 & 2.2 & 2.1 & 15.7 \\
\hline $\begin{array}{l}\text { Cow with calf } \\
\text { ( } 5 \text { years) }\end{array}$ & 115 & 28.2 & 0.38 & 75 & 11.32 & 2.5 & 2.2 & 17.7 \\
\hline Bull (3 years) & 125 & 25.1 & 0.33 & 75 & 11.32 & 2.2 & 1.8 & 15.8 \\
\hline Bull (5 years) & 135 & 25.3 & 0.34 & 75 & 11.32 & 2.2 & 1.7 & 15.9 \\
\hline Average & 105.7 & 22.6 & 0.30 & 75 & 11.32 & 2.0 & 1.9 & 14.3 \\
\hline
\end{tabular}

LSU: large stock unit; ME: metabolizable energy; DE: digestibility; DM: dry matter; LW: liveweight;

$\mathrm{CH}_{4}:$ methane; $\mathrm{kg} / \mathrm{h} /$ year $=\mathrm{kg} / \mathrm{head} / \mathrm{year}$. 
Appendix 2D Breakdown of animal species, energy requirements, diet characteristics, intake and annual enteric methane emissions

\begin{tabular}{|c|c|c|c|c|c|c|c|c|}
\hline \multirow[b]{2}{*}{ Animal species } & \multicolumn{2}{|c|}{$\begin{array}{c}\text { Animal } \\
\text { characteristics }\end{array}$} & \multirow[b]{2}{*}{ LSU } & \multicolumn{2}{|c|}{$\begin{array}{c}\text { Diet } \\
\text { characteristics } \\
\end{array}$} & \multirow{2}{*}{$\begin{array}{l}\text { Intake (kg } \\
\text { DM/day) }\end{array}$} & \multirow{2}{*}{$\begin{array}{c}\text { Intake } \\
(\% / L W)\end{array}$} & \multirow{2}{*}{$\begin{array}{c}\mathrm{CH}_{4} \\
(\mathrm{~kg} / \mathrm{h} / \text { day })\end{array}$} \\
\hline & $\begin{array}{l}\text { Weight } \\
\text { (kg) }\end{array}$ & $\begin{array}{c}\text { ME } \\
\text { requirements } \\
\text { (MJ/day) }\end{array}$ & & $\begin{array}{c}\text { Diet } \\
\text { DE\% }\end{array}$ & $\begin{array}{c}\mathrm{ME} \\
\mathrm{MJ} / \mathrm{kg}\end{array}$ & & & \\
\hline \multicolumn{9}{|l|}{ Tsessebe } \\
\hline $\begin{array}{l}\text { Lamb } \\
\text { (5 months) }\end{array}$ & 38 & 12.2 & 0.16 & 65 & 11.32 & 1.1 & 2.8 & 8.0 \\
\hline $\begin{array}{l}\text { Ewe dry } \\
\text { (3 years) }\end{array}$ & 104 & 19.6 & 0.26 & 65 & 11.32 & 1.7 & 1.7 & 12.5 \\
\hline $\begin{array}{l}\text { Ewe dry } \\
\text { (5 years) }\end{array}$ & 113 & 20.9 & 0.28 & 65 & 11.32 & 1.8 & 1.6 & 13.3 \\
\hline $\begin{array}{l}\text { Ewe with lamb } \\
\text { (3 years) }\end{array}$ & 104 & 24.6 & 0.33 & 65 & 11.32 & 2.2 & 2.1 & 15.5 \\
\hline $\begin{array}{l}\text { Ewe with lamb } \\
\text { (5 years) }\end{array}$ & 113 & 27.2 & 0.36 & 65 & 11.32 & 2.4 & 2.1 & 17.1 \\
\hline Ram (3 years) & 126 & 24.2 & 0.32 & 65 & 11.32 & 2.1 & 1.7 & 15.3 \\
\hline Ram (5 years) & 138 & 24.2 & 0.32 & 65 & 11.32 & 2.1 & 1.5 & 15.3 \\
\hline Average & 105.1 & 21.8 & 0.29 & 65 & 11.32 & 1.9 & 1.8 & 13.8 \\
\hline \multicolumn{9}{|l|}{ Blesbok } \\
\hline $\begin{array}{l}\text { Lamb } \\
\text { (5 months) }\end{array}$ & 23 & 7.6 & 0.10 & 75 & 11.32 & 0.7 & 2.9 & 5.2 \\
\hline $\begin{array}{l}\text { Ewe dry } \\
\text { ( } 3 \text { years) }\end{array}$ & 60 & 12.3 & 0.16 & 75 & 11.32 & 1.1 & 1.8 & 8.0 \\
\hline $\begin{array}{l}\text { Ewe dry } \\
\text { (5 years) }\end{array}$ & 67 & 14.7 & 0.20 & 75 & 11.32 & 1.3 & 1.9 & 9.5 \\
\hline $\begin{array}{l}\text { Ewe with lamb } \\
\text { (3 years) }\end{array}$ & 60 & 15.4 & 0.21 & 75 & 11.32 & 1.4 & 2.3 & 9.9 \\
\hline $\begin{array}{l}\text { Ewe with lamb } \\
\text { (5 years) }\end{array}$ & 67 & 19.1 & 0.25 & 75 & 11.32 & 1.7 & 2.5 & 12.2 \\
\hline Ram (3 years) & 73 & 14.3 & 0.19 & 75 & 11.32 & 1.3 & 1.7 & 9.3 \\
\hline Ram (5 years) & 81 & 14.8 & 0.20 & 75 & 11.32 & 1.3 & 1.6 & 9.6 \\
\hline Average & 61.6 & 14.0 & 0.19 & 75 & 11.32 & 1.2 & 2.0 & 9.1 \\
\hline \multicolumn{9}{|l|}{ Warthog } \\
\hline $\begin{array}{l}\text { Piglet } \\
\text { (3 months) }\end{array}$ & 13 & 6.2 & 0.08 & 75 & 11.32 & 0.5 & 4.2 & 3.6 \\
\hline $\begin{array}{l}\text { Sow dry } \\
(2 \text { years) }\end{array}$ & 59 & 15.0 & 0.20 & 75 & 11.32 & 1.3 & 2.2 & 1.9 \\
\hline $\begin{array}{l}\text { Sow dry } \\
\text { (3 years) }\end{array}$ & 65 & 13.9 & 0.19 & 75 & 11.32 & 1.2 & 1.9 & 1.6 \\
\hline $\begin{array}{l}\text { Sow with litter } \\
\text { ( } 2 \text { years) }\end{array}$ & 59 & 21.1 & 0.28 & 75 & 11.32 & 1.9 & 3.2 & 2.7 \\
\hline $\begin{array}{l}\text { Sow with litter } \\
\text { ( } 3 \text { years) }\end{array}$ & 65 & 20.1 & 0.27 & 75 & 11.32 & 1.8 & 2.7 & 2.3 \\
\hline Boar (2 years) & 74 & 18.4 & 0.25 & 75 & 11.32 & 1.6 & 2.2 & 1.9 \\
\hline Boar (3 years) & 80 & 16.2 & 0.22 & 75 & 11.32 & 1.4 & 1.8 & 1.5 \\
\hline Average & 59.3 & 15.8 & 0.21 & 75 & 11.32 & 1.4 & 2.4 & 2.2 \\
\hline
\end{tabular}

LSU: large stock unit; ME: metabolizable energy; DE: digestibility; DM: dry matter; LW: liveweight;

$\mathrm{CH}_{4}$ : methane; $\mathrm{kg} / \mathrm{h} /$ year $=\mathrm{kg} / \mathrm{head} /$ year. 
Appendix 2E Breakdown of animal species, energy requirements, diet characteristics, intake and annual enteric methane emissions

\begin{tabular}{|c|c|c|c|c|c|c|c|c|}
\hline \multirow[b]{2}{*}{ Animal species } & \multicolumn{2}{|c|}{$\begin{array}{c}\text { Animal } \\
\text { characteristics }\end{array}$} & \multirow[b]{2}{*}{ LSU } & \multicolumn{2}{|c|}{$\begin{array}{c}\text { Diet } \\
\text { characteristics }\end{array}$} & \multirow{2}{*}{$\begin{array}{c}\text { Intake (kg } \\
\text { DM/day) }\end{array}$} & \multirow{2}{*}{$\begin{array}{c}\text { Intake } \\
(\% / L W)\end{array}$} & \multirow{2}{*}{$\begin{array}{c}\mathrm{CH}_{4} \\
\text { (kg/h/day) }\end{array}$} \\
\hline & $\begin{array}{l}\text { Weight } \\
\text { (kg) }\end{array}$ & $\begin{array}{c}\text { ME } \\
\text { requirements } \\
\text { (MJ/day) }\end{array}$ & & $\begin{array}{c}\text { Diet } \\
\text { DE\% }\end{array}$ & $\begin{array}{c}\text { ME } \\
\text { MJ/day }\end{array}$ & & & \\
\hline \multicolumn{9}{|l|}{ Impala } \\
\hline $\begin{array}{l}\text { Lamb } \\
\text { (4 months) }\end{array}$ & 19 & 5.8 & 0.08 & 75 & 11.32 & 0.5 & 2.7 & 4.1 \\
\hline $\begin{array}{l}\text { Ewe dry } \\
\text { ( } 2 \text { years) }\end{array}$ & 37 & 10.8 & 0.14 & 75 & 11.32 & 1.0 & 2.6 & 7.1 \\
\hline $\begin{array}{l}\text { Ewe dry } \\
\text { (4 years) }\end{array}$ & 45 & 10.2 & 0.14 & 75 & 11.32 & 0.9 & 2.0 & 6.8 \\
\hline $\begin{array}{l}\text { Ewe with lamb } \\
\text { ( } 2 \text { years) }\end{array}$ & 37 & 14.0 & 0.19 & 75 & 11.32 & 1.2 & 3.3 & 9.1 \\
\hline $\begin{array}{l}\text { Ewe with lamb } \\
\text { (4 years) }\end{array}$ & 45 & 13.9 & 0.19 & 75 & 11.32 & 1.2 & 2.7 & 9.0 \\
\hline Ram (2 years) & 51 & 11.9 & 0.16 & 75 & 11.32 & 1.1 & 2.1 & 7.8 \\
\hline Ram (4 years) & 60 & 12.2 & 0.16 & 75 & 11.32 & 1.1 & 1.8 & 8.0 \\
\hline Average & 42 & 11.3 & 0.15 & 75 & 11.32 & 1.0 & 2.4 & 7.4 \\
\hline \multicolumn{9}{|l|}{ Springbok } \\
\hline $\begin{array}{l}\text { Lamb } \\
\text { (2.5 months) }\end{array}$ & 12 & 3.2 & 0.04 & 75 & 11.32 & 0.3 & 2.3 & 2.5 \\
\hline $\begin{array}{l}\text { Ewe dry } \\
\text { (18 months) }\end{array}$ & 27 & 6.3 & 0.08 & 75 & 11.32 & 0.6 & 2.1 & 4.4 \\
\hline $\begin{array}{l}\text { Ewe dry } \\
\text { (3 years) }\end{array}$ & 31 & 7.0 & 0.09 & 75 & 11.32 & 0.6 & 2.0 & 4.8 \\
\hline $\begin{array}{l}\text { Ewe with lamb } \\
\text { (18 months) }\end{array}$ & 27 & 7.9 & 0.10 & 75 & 11.32 & 0.7 & 2.6 & 5.3 \\
\hline $\begin{array}{l}\text { Ewe with lamb } \\
\text { (3 years) }\end{array}$ & 31 & 9.1 & 0.12 & 75 & 11.32 & 0.8 & 2.6 & 6.1 \\
\hline $\begin{array}{l}\text { Ram } \\
\text { (18 months) }\end{array}$ & 30 & 7.1 & 0.09 & 75 & 11.32 & 0.6 & 2.1 & 4.9 \\
\hline Ram (3 years) & 36 & 7.4 & 0.10 & 75 & 11.32 & 0.7 & 1.8 & 5.0 \\
\hline Average & 27.7 & 6.8 & 0.09 & 75 & 11.32 & 0.6 & 2.2 & 4.7 \\
\hline
\end{tabular}

LSU: large stock unit; ME: metabolizable energy; DE: digestibility; DM: dry matter; LW: liveweight; $\mathrm{CH}_{4}$ : methane; $\mathrm{kg} / \mathrm{h} /$ year $=\mathrm{kg} / \mathrm{head} /$ year. 